Historic, Archive Document

Do not assume content reflects current scientific knowledge, policies, or practices. 

A. 建. Austín Co.

\author{
WAYLAND, OHIO
}

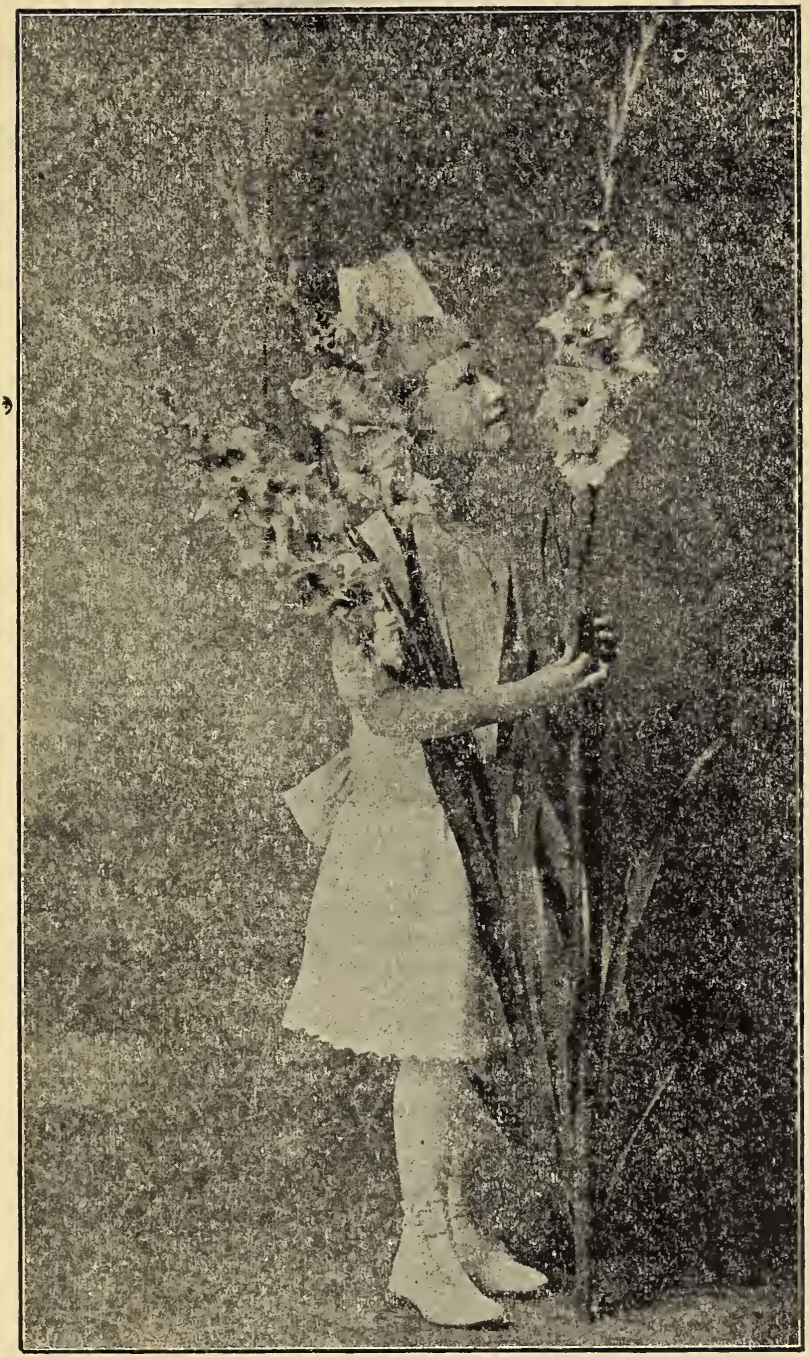

EVELYN KIRTLAND

ADDRESS ALL ORDERS FROM THIS LIST TO

A. H. AUSTIN CO.

HOME OF ELIM HILL GLADIOLUS

WAYLAND, OHIO 


\section{RETAIL PRICE LIST OF GLADIOLUS}

\section{GROWN AT \\ ELM HILL FARM, WAYLAND, OHIO \\ PRICES FOR BLOOMING SIZE BULBS}

\section{Per \\ Ea. \\ AUSTIN ORIGINATIONS}

Evelyn Kirtland. Dark rosy pink at edges, shading to shell pink at center with brilliant scarlet blotches on lower petals. Very tall.

Cardisun. Very dark cardinal red with almost black throat...........................

Bertrex. White. Many flowers open at one time

Gretchen Zang. Large, soft pink blending to scarlet on lower petals........

Golden Swallow. Soft yellow. No throat markings. Beautifully ruffled......

Herada. Mauve, glistening and pure...

Mary Bellard. White, wide open flowers. Lavender markings on lower petals

Yellow Treasure. New. Clear rich yellow. Ruffled.......................................

Tycko Zang. New. Clear salmon pink with white throat. 5 in. flowers............ $\$ 3.00$

\section{STANDARD VARIETIES}

Albania.....Pure silvery white, daintily ruffled.

Alice Tiplady. Large, orange color....

America. Lavender pink....................

Baron Hulot. Velvetly purple........-...

Beaconflame. Flame scarlet.................

B. L. Smith. Wonderful shade of

lavender pink ..........................................

Crimson Glow. Brilliant, velvetly

crimson. Large................................... flower, slightly penciled lilac..................

E. J. Shaylor. Beautiful pure, deep rose pink.

Elizabeth Tabor. Similar to Pendleton. Much earlier.....................................

Empress of India. Very dark velvetly red with white markings in throat
$\$ 1.00$
Per

Doz.

Ea.

Flora. Canary yellow. Strong grower

Gold Drop.....Fine large yellow prim.

Halley. Salmon pink. Very early....

Illuminator. Brilliant carmine red.

French blue throat.

LeMar. Foch. Delicate pink. Large, wide open. Very early............................ Lily White. A fine pure white. Early ............................. Prim.

Louise. Orchid like flower of clear blue-lavender with wine blotch in throat

Mrs. Dr. Norton. Delicate cream and pink. One of the finest....................

Mrs. Frances King. Flame color. Tall

Mrs. Frank Pendleton. Large, tall grower. Rose pink with carmine blotch

Mrs. Watt. Color of American Beauty Rose.

Myrtle. Arbutus pink. Early..

Niagara. Creamy yellow with primrose throat.

Orange Brilliant. Pure orange. Prim.

Panama. Large rose pink.

Pink Wonder. Large light pink.

6 in. flowers

Primulinus Hybrids--(Mixed)--A fine mixture of choice prims...............................

Schwaben. Very large, light yellow....

Twilight. Creamy white. Throat of blended pink and yellow.

Wilbrink. Delicate pale pink. Very early

Willy. Wigman. White flushed pink....

Dr. R. P. Jackson. Dark velvety red.. 

Elm Hill Farm is centrally located in one of the great flower growing sections of the United States, being about midway between Cleveland and Pittsburg on the improved Inter-County Highway between Akron and Warren, one mile west of Wayland Station and seven miles east of Ravenna, Ohio. R. C. Bellard, Mgr.

Trial Grounds and Residence of A. H. AUSTIN 356 N. Freedom Street, Ravenna, Ohio

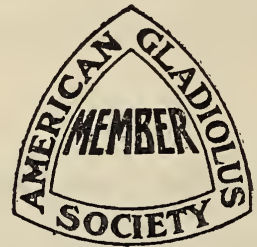

\section{BUSINESS OFFICE AT FARM WAYLAND. OHIO}

TELEPHONE AND TELEGRAPH, RAVENNA, OHIO EXPRESS OFFICE, WAYLAND, OHIO

ALL MONEY ORDERS PAYABLE AT RAVENNA. O.

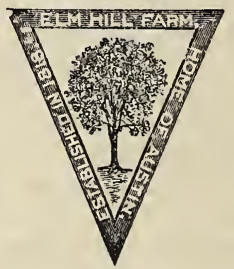

TERMS OF SALE

Our terms are net cash where credit has not been established with us. We will hold bulbs for Spring delivery on a deposit of 25 per cent.

WHOLESALE PRICE LIST UPON REQUEST

ADDRESS ALL ORDERS FROM THIS LIST TO A. H. AUSTIN CO. HOME OF ELM HILL GLADIOLUS

R. C. BELLARD, MGR. WAYLAND, OHIO 